\title{
Tetiana Iemelianova
}

(Uniwersytet Przyrodniczo-Humanistyczny w Siedlcach, Siedlce - Polska)

\section{МОАААЬНАЯ ОРГАНИЗАЦИЯ АИААОГИЧЕСКОЙ И МОНОАОГИЧЕСКОЙ РЕЧИ}

Спілкування є невід'ємним атрибутом людського життя. 3 цим пов' язане існування різних засобів комунікації - як вербальних, так і невербальних.

Кожна інформація так чи так містить інтенції автора, тобто виражає його ставлення до повідомленої ним думки.

У лінгвістиці це явище окреслюють поняттям „модальність”, що має таку дефініцію:

Модальність - це лінгвістична категорія, що виражає ставлення мовця до змісту сказаного, або мовна універсалія, функціонально-семантична категорія мови й одна з ознак речення 1 .

Здавна категорія модальності привертала увагу філософів, логіків, лінгвістів. Уперше це поняття вводить Аристотель, створюючи нову науку - логіку.

У роботах російських та українських лінгвістів модальність розглядають у межах вивчення категорії способу дієслова: ऑї характеризують як таку, що виражає відношення дії до дійсності. Разом із тим, у мовознавстві розроблені різні класифікації модальних слів (часток, допоміжних дієслів, модальних прикметників, слів категоpiї стану і т. ін.), що стали основними засобами вираження модальності в реченні.

Докладну характеристику категорії модальності пропонує швейцарський лінгвіст Шарль Баллі ${ }^{2}$, зауважуючи, що речення - це найпростіша можлива форма повідомлення думки. Мислити - означає реагувати на уявлення, констатуючи його наявність, оцінюючи чи бажаючи його. У першому випадку виражається „судження про факт”, у другому - „судження про цінність факту”, а в третьому - „волевияв".

У русистиці категорію модальності всебічно описав Ви́ктор Влади́мирович Виноградов. Зважаючи на засоби вираження реальності

1 О. Селіванова, Сучасна лінгвістика: термінологічна енциклопедія, Полтава 2006, c. 382-384.

2 Ш. Балли, Общзая лингвистика и вопросы франиузского языка, Москва 1955. 
та ірреальності, дослідник виокремив суб'єктивну й об'єктивну модальність ${ }^{3}$. Але оскільки сказане (текст) є віддзеркаленням дійсності в людському мисленні, то це значить, що модальність за своєю природою не може бути об'єктивною. Погоджуємося 3 тезою біхевіористів про можливість заперечення існування об'єктивного світу. Світ такий, яким його бачить людина, яким вона його сприймає.

Розвиваючи ідеї про модальну організацію речень, Баллі доходить висновку, що не можна надавати статус „речення” висловленню, якщо в ньому не виражена модальності. Якщо відсутні формальні показники модальності - вони можуть бути імпліцитними, але вони обов' язково є.

В основу проведеного аналізу покладено ідею модальної рамки, що сформульована Баллі. Відповідно до його теорії кожне окреме висловлення природної мови характеризується наявністю модальної структури як ії обов' язкового компонента. Розвиваючи цю ідею, можна припустити, що модальна рамка характерна не лише для окремого висловлення, але й для тексту загалом.

На думку Баллі, текст відображає певну послідовність у вираженні думок. Спочатку мовець демонструє свої знання, потім на основі цих знань у нього виникають відповідні міркування, а далі на основі своїх знань і міркувань він робить певні висновки (висловлює бажання) ${ }^{4}$.

Ця ідея, з одного боку, є логічною і значущою, але, з іншого, - автор не наводить прикладів для демонстрації модальної рамки в конкретному тексті. Це, очевидно, можна зробити, поєднавши ідеї Баллі з ідеями польської дослідниці Анны Вєжбіцької щодо семантичних примітивів як форм виявлення думок та інтенцій мовця.

Для передачі практично будь-якого змісту, на думку дослідниці, достатньо створити певну кількість примітивів, що були б зрозумілими всім людям і могли б служити основою для пояснення кожного конкретного поняття.

Основними предикатами інтелектуальної діяльності Вежбіцька вважає поняття „знати” та „мислити”. До них (також як основний) додається предикат волевияву „хотіти”. Саме ці предикати виокремлюють як основні через те, що їх не можна отримати чи пояснити за допомогою інших понять. Вони є ніби точкою відліку для створення тієї сукупності понять, що існує в певній мові, тобто

${ }^{3}$ В.В. Виноградов, Русский язык (грамматическое учение о слове), Москва 1986, с. $474-$ 475.

${ }^{4}$ Ш. Балли, Язык и жизнъ, [в:] Шарль Балли, пер. с фр. И.И. Челышевой, Е.А. Вельмезовой; вступ. ст. В.Г. Гака, Москва 2003. 
кожне висловлення природної мови можна подати у вигляді семантичного примітиву, або семантичної експлікації. Відповідно, при розгортанні речення мовці використовують один з трьох основних типів висловлень, які в структурі містять один з трьох вищенаведених предикатів: 'Я знаю, що', 'Я думаю, що', 'Я хочу, щоб'. Послуговуючись ідеєю розгортання кожного речення в семантичний примітив, ми провели аналіз усіх вибраних нами текстів 5 .

Як зазначалося, кожен текст має певну структуру, яку називаємо модальною рамкою. Вона може бути виявлена лише за допомогою семантичної експлікації кожного речення і перетворення його в семантичний примітив.

Висловлення типу 'я знаю що', як правило, становлять мериторичні знання, інакше кажучи, вони розповідають про світ так званих об'єктивних речей. Їх зазвичай відносять до висловлень 3 „епістемічною” модальністю. Висловлення типу 'я думаю, що' містять результати мисленнєвої діяльності адресанта: їх відносять до висловлень 3 „асерторичною” модальністю. Нарешті, висловлення типу 'я хочу, щоб' виражають усвідомлення адресанта (мовця), що він $є$ (або може бути) суб'єктом певних бажань: їх називають висловленнями 3 „деонтичною" модальністю 6.

За основу дослідження було взято статті політичного змісту, які $\epsilon$ прикладами монологічного мовлення, i діалог 3 п'єси Івана Котляревського Наталка Полтавка.

Особливості модальної організації монологічного тексту продемонструємо на прикладі аналізу двох статей, автором яких є історик, політолог Олександр Палій. Одна зі статей має назву Зовнішня політика кандидатів: все сусідам, собі попелище, а інша - Чому важко пишеться „спільна" історія, і легко - вітчизняна?8. Для прикладу подамо кілька експлікацій.

Перша стаття починається так: (1) „Назовні критика президентом Віктором Ющенком прем'єр-міністра Юлії Тимошенко не завжди виглядала раціональною”, (2) „Але вона не була беззмістовною, принаймні у своїй частині". Ці речення експлікуємо так:

${ }^{5}$ A. Wierzbicka, Semantic Primitives and Lexical Universals, "Quaderni di Semantica" 1989, nr 19, c. 103-121.

6 J. Puzynina, O znaczeniu czasownika „oceniać" we wspótczesnym jezzyku polskim, "Studia Gramatyczne IV", Wrocław 1981, c. 113-126.

${ }^{7}$ О. Палій, Зовнішня політика кандидатів: все сусідам, собі попелище, http://www.pravda. com.ua/columns/2010/01/15/4620563/ (02.11.2011).

8 О. Палій, Чому Важко пишеться „спільна" історія, і легко - вітчизняна?, http:// www.pravda. com.ua/articles/2011/02/9/5895669/ (07.12.2011). 
$\left(1^{*}\right)$ „Я думаю, що критика президентом Віктором Ющенком прем'єр-міністра Юлії Тимошенко не завжди виглядала раціональною. Ірраціоналізм політика $\rightarrow$ це погано $\rightarrow$ Ющенко - поганий по_літик $\rightarrow$ Ющенко треба замінити".

$\left(2^{*}\right)$ „Я думаю, що така критика не є безпідставною і беззмістовною, хоча б частково, змістовність критики вказує на недоліки роботи прем'єр-міністра. Того, хто працює зараз з недоліками, треба замінити $\rightarrow$ Тимошенко не повинна бути при владі".

I далі наприклад речення (3) „Питання НАТО дуже чітко ілюструє, що для кандидатів є важливішим - доля українського народу, чи позиція керівництва сусідньої держави" має експлікацію:

$\left(3^{*}\right)$ „Я думаю, що питання про вступ до НАТО ілюструє нам те, що для кандидатів у президенти є важливішим: не український народ та його майбутнє, а позиція керівництва сусідньої держави. Незацікавленість українським народом $\rightarrow$ байдужість до майбутнього України $\rightarrow$ висування на перший план власних інтересів $\rightarrow$ це погано $\rightarrow$ кандидати на посаду президента погані $\rightarrow$ їх обирати не треба".

Повний аналіз показав, що основну частину цієї статті становлять речення, в яких автор висловлює свої думки. Ці речення чергуються 3 реченнями інформативного типу, але вони також $є$ реченнями оцінними, що виражають аксіологічні смисли. Модальна рамка статті виглядає так:

Таблиця 1

\begin{tabular}{|l|l|}
\hline Я думаю & 3 речення \\
\hline Я знаю & 6 речень \\
\hline Я думаю & 4 речення \\
\hline Я знаю & 4 речення \\
\hline Я думаю & 1 речення \\
\hline Я знаю & 1 речення \\
\hline Я думаю & 8 речень \\
\hline Я знаю & 2 речення \\
\hline Я думаю & 4 речення \\
\hline Я знаю & 1 речення \\
\hline Л думаю & 7 речень \\
\hline Я знаю & 3 речення \\
\hline Я думаю & 5 речень \\
\hline Я знаю & 3 речення \\
\hline Я думаю & 6 речень \\
\hline Я хочу & 1 речення \\
\hline Я знаю & 1 речення \\
\hline Я хочу & 3 речення \\
\hline
\end{tabular}


Друга стаття також цікава з огляду на змістове наповнення. Всі речення були експліковані за тим самим принципом, що і попередні. Подамо кілька речень для прикладу та охарактеризуємо загальну модальну рамку тексту.

Речення (4) „Досі немає результатів у написанні методологічного посібника для вчителів, створити який до листопада минулого року обіцяв Дмитро Табачник" має експлікацію:

$\left(4^{*}\right)$ „Я Знаю, що Дмитро Табачник не виконав своєї обіцянки - створити методологічний посібник для вчителів (до листопада місяця). Він безвідповідальна людина".

Наступне речення (5) „До останнього влада явно не готова, тому пішла тихцем - викреслюючи із підручників для дітей украй важливі для України події - Крути, Голодомор, Мазепу, Батурин тощо" має відповідну експлікацію:

$\left(5^{*}\right)$ „Я думаю, що наша влада вчинила не добре, викреслюючи 3 підручників важливі в історії України події, які повинні знати і вивчати всі громадяни. Влада своїми діями хоче прислужитися Росії. Влада не має так чинити - це свідчить про іiі безвідповідальність та нечесність". Семантичним центром цієї конструкції $\epsilon$ прислівник „тихцем”, що має негативне забарвлення. Саме цей прислівник визначає те, що весь зміст конструкції містить негативну оцінку.

Наступне речення (6) „Історія не дає зникнути урокам, які бере для себе кожне нове покоління, вона, по суті, є союзом між живими, мертвими і ненародженими" має експлікацію:

$\left(6^{*}\right)$ „Я думаю, що саме історія навчає народ тому, як жити, як чинити, що робити, щоб життя було приємним. Історія пов'язує між собою минуле, сучасність і майбутнє. Без них навіть будь-яка окрема людина не може існувати, тому ми маємо не допустити знищення власної історії".

Ця стаття має дещо іншу структуру. Модальна рамка цього тексту - стандартна. У ній більшу частину становлять речення типу 'Я думаю, що' (81 речення з 85). Речення інших типів представлені в мінімальній кількості:

\begin{tabular}{|l|r|}
\hline Я знаю & 3 речення \\
\hline Я думаю & 81 речення \\
\hline Я хочу & 1 речення \\
\hline
\end{tabular}

Такі розбіжності в модальній структурі статей зумовлені тим, що автор ставить перед собою різні завдання. Перша стаття, що написана в період передвиборчої кампанії, мала на меті схилити читача до певних дій під час виборів. Текст має виразно персуазив- 
ний характер. Автор не дає читачеві права вибору, він робить його сам і намагається переконати інших у своїй правильності.

У другій статті бачимо лише висловлення власних думок автора. Він репрезентує власні позиції, але вже не намагається схилити читача до певного вибору, тобто тут вибір залишається за читачем. Проаналізовані статті являють собою монологічний тип мовлення, оскільки автор виражає власні думки, власне бачення проблем.

Проте зазначимо, що монолог є вторинним типом мовлення. Він з'являється внаслідок тривалого і складного процесу розвитку людського мислення. Первинною ж формою функціонування мовлення як феномену людського буття є діалог. Мовлення з'являється як діалог. Власне тому цікаво простежити процес формування модальної рамки в діалозі. Таке звернення до зіставного аналізу, на нашу думку, дасть можливість краще зрозуміти природу категорії модальності як текстотвірної універсалії.

Прикладом, що демонструє ці особливості діалогічного мовлення, може бути діалог, узятий з тексту твору Котляревського Наталка Полтавка9. Діалог такий:

В о з н ы й. 1* „Благоденственного і мирного пребиванія! (В сторону). $2^{*}$ Удобная оказія предстала зділати о собі предложеніє на самоті". ний!".

H $a m a \wedge \kappa a$. (кланяясь). 1) „Здорові були, добродію, пане воз-

В о з н ы й. $3^{*}$, «Добродію!» «Добродію!» Я хотів би, щоб ти звала мене - теє-то як його - не вишепом' янутим ім' ям".

H $\boldsymbol{a} \boldsymbol{m} \boldsymbol{a} \boldsymbol{\wedge} \boldsymbol{\kappa} \boldsymbol{a} .2$ ) "Я вас зову так, як все село наше величає, шануючи ваше письменство і розум".

В о $з \boldsymbol{\mu}$ ы $\tilde{u} .4^{*}$ "Не о сем, галочко, - теє-то як його - хлопочу я, но желаю із медових уст твоїх слишати умилительноє названіє, сообразноє моєму чувствію”. (пісня) $5^{*}$ „Не в состоянії поставить на вид

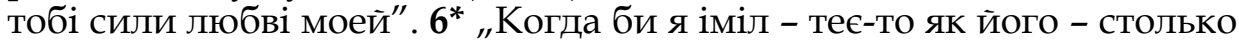
язиков, сколько артикулов в Статуті ілі сколько зап'ятих в Магдебурзьком праві, то і сих не довліло би навосхваленіє ліпоти твоєй!" $7^{*}$ "Ей-єй, люблю тебе до безконечності".

Н $a m a \wedge \kappa a$. 3) „Бог з вами, добродію! Що ви говорите! Я річі вашей в толк собі не возьму".

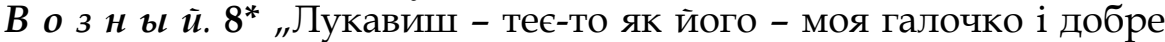
все розумієш”. 9* „Ну, коли так, я тобі коротенько скажу: я тебе люблю і женитись на тобі хочу".

$H \boldsymbol{a} \boldsymbol{m} \boldsymbol{a} \wedge \boldsymbol{\kappa} \boldsymbol{a}$. 4) „Гріх вам над бідною дівкою глумитися; чи я вам рівня?” 5) „Ви пан, а я сирота; ви багатий, а я бідна; ви возний, а я простого роду; та й по всьому я вам не під пару".

\footnotetext{
${ }^{9}$ І. Котляревський, П. Енеїда, Наталка-Полтавка, Донецьк 2007.
} 
В $\boldsymbol{o} з \boldsymbol{\mu} \boldsymbol{b} \boldsymbol{u} \cdot 10^{*}$ „ІІзложенниї в отвітних річах твоїх резони суть - теє-то як його - для любові ничтожні”. 11* „Уязвленное частореченною любовію серце, по всім божеським і чоловічеським законам, не взираєть ні на породу, ні на літа, ні на состояніє”. 12* „Оная любов все - теє-то як його - ровняєть”. 13* „Рци одно слово: «Люблю вас, пане возний!» - і аз, вишеупом'янутий, виконаю присягу о вірном і вічном союзі з тобою".

H $\boldsymbol{a} \boldsymbol{m} \boldsymbol{a} \boldsymbol{\wedge} \boldsymbol{\kappa} \boldsymbol{a} . \mathbf{6 )}$ „У вас єсть пословиця: «Знайся кінь 3 конем, а віл з волом»; шукайте собі, добродію, в городі панночки; чи там трохи єсть суддівен, писарівен і гарних попівен?”. 7) „Любую вибирайте...” 8) „Ось підіть лиш в неділю або в празник по Полтаві, то побачите таких гарних, що і розказати не можна".

В о з н ы $\tilde{u} .14^{*}$ „Бачив я многих - і ліпообразних, і багатих, но серце моє не імієть - теє-то як його - к ним поползновенія". 15* „Ти одна заложила ему позов на вічнії роки, і душа моя єжечасно волаєть тебе і послі нишпорной даже години".

H $a \boldsymbol{m} \boldsymbol{a} \wedge \boldsymbol{\kappa} \boldsymbol{a} .9)$ „Воля ваша, добродію, а ви так 3-письменна говорите, що я того і не зрозумію; та і не вірю, щоб так швидко і дуже залюбитись можна".

В о з н ы й. 16* „Не віриш?” 17* „Так знай же, що я тебе давно уже - теє-то як його - полюбив, як тілько ви перейшли жити в нашеє село”. 18* „Моїх діл околичності, возникающії із неудобних обстоятельств, удерживали соділати признаніє пред тобою; тепер же, читая - теє-то як його - благость в очах твоїх, до формального опреділенія о моєй участі, открой мні, хотя в терміні, партикулярно, резолюцію: могу лі - теє-то як його - без отсрочок, волокити, проторов і убитков получити во вічноє і потомственноє владініє тебе - движимоє і недвижимоє імініє для душі моєй - 3 правом владіти тобою спокойно, безпрекословно і по своєй волі - теє-то як його - розпоряджать?”. 19* „Скажи, говори, отвічай, отвітствуй, могу лі бить - теє-то як його - мужем пристойним і угодним душі твоєй і тілу?".

H $\boldsymbol{a} \boldsymbol{m} \boldsymbol{a} \boldsymbol{\wedge} \boldsymbol{\kappa} \boldsymbol{a}$ (пісня). „Так, добродію, пане возний!” 10) „Перестаньте жартовати надо мною, безпомощною сиротою”. 11) „Моє все багатство єсть моє добре ім'я; через вас люди начнуть шептати про мене, а для дівки, коли об ній люди зашепчуть...".

Кожне з цих речень було трансформоване на семантичний примітив за допомогою трьох єдностей, про які йшлося раніше. Тепер, виділивши окремо репліки кожного з героїв та провівши семантичні експлікації кожного висловлення, можемо репрезентувати вияв модальної рамки в тексті: 
НАТАЛКА

\begin{tabular}{|l|c|}
\hline Я хочу & 1 речення \\
\hline Я знаю & 1 речення \\
\hline & \\
Я думаю & 7 речень \\
& \\
\hline Я хочу & 2 речення \\
\hline
\end{tabular}

ВОЗНИЙ

\begin{tabular}{|l|l|}
\hline Я хочу & 1 речення \\
\hline Я думаю & 1 речення \\
\hline Я хочу & 1 речення \\
\hline Я думаю & 4 речення \\
\hline Я хочу & 1 речення \\
\hline Я думаю & 3 речення \\
\hline Я хочу & 1 речення \\
\hline Я думаю & 1 речення \\
\hline Я хочу & 1 речення \\
\hline Я думаю & 2 речення \\
\hline Я хочу & 2 речення \\
\hline
\end{tabular}

У цьому діалозі фіксуємо наявність усіх елементів модальної рамки.

Проведений аналіз дає можливість констатувати, що кожен з учасників діалогу послідовно вибудовує свою лінію. Для Возного це сфера висловлення бажань. Саме тому майже $40 \%$ його висловлень експліковані формулою типу 'Я хочу, щоб'. Репліки Наталки демонструють цілісність натури, що на підставі своєї мисленнєвої діяльності (висловлення типу 'Я думаю, що', яких у неї майже 65\%) досить категорично формулює бажання припинити дії свого співрозмовника.

Збіг модальної семантики в репліках обох учасників діалогу ( $\approx 60 \%$ висловлень типу 'Я думаю, що' у Возного і $\approx 65 \%$ висловлень такого ж типу в Наталки) забезпечує успішність його побудови. Учасники діалогу розуміють один одного, а отже, можна стверджувати, що кожен із них досяг своєї комунікативної мети, а такі чинники, як задоволеність результатами діалогу, до уваги не беруться.

Узагалі за своєю природою діалог повинен бути вдалим. Первинно він виникає як успішний комунікативний акт, тому розмова зазвичай відбувається лише між людьми, які можуть обмінюватися певною інформацією і мати вигоду з розмови.

Як бачимо, текст Котляревського, а власне діалоги між героями, справді, є зразком того, як слід моделювати комунікативний акт.

Дослідження та зіставлення подібних текстів з огляду на лінгвістику дає підстави стверджувати, що тексти діалогічні за своєю будовою та модальною організацією $є$ набагато складнішими, ніж тексти монологічні.

Зазначене пояснюється тим, що в монологічному тексті лише одна людина створює мовлення, вона сама вибирає, як будувати своє висловлення. У діалогічному ж мовленні ситуація складніша, 
оскільки діалог будують дві особи. Між ними повинен існувати консенсус у момент обміну думками: вони повинні розуміти один одного і моделювати відповідь залежно від того, що вимагає співбесідник. Якщо узгодженості між мовцями не буде, тобто модальні рамки їх висловлень будуть різні, то вони не зможуть побудувати діалог, або він буде невдалим чи взагалі не відбудеться.

У перспективі вивчення цієї проблеми може бути скероване на з'ясування того, чим відрізняються тексти, створені чоловіком, від текстів, змодельованих жінкою. Такі дослідження, очевидно, дадуть змогу відповісти на питання, як впливає гендерний чинник на модальну організацію тексту. 